DOI 10.4467/2543733XSSB.21.013.13806

PIOTR ŻUREK

Akademia Techniczno-Humanistyczna w Bielsku-Białej

\title{
GAZIMESTAN 28 CZERWCA 1989 ROKU - FRAZEOLOGIA PRZEMÓWIENIA SLOBODANA MILOŠEVICIA
}

\author{
Gazimestan June 28, 1989 - Phraseology \\ of the Speech \\ of Slobodan Milošević
}

Summary

In 2019, the thirtieth anniversary of the famous speech of Slobodan Milošević delivered on the day of St. Vitus (Vidovdan) on June 28, 1989, on 600th anniversary of the Battle of Kosovo, was marked. This speech was considered ominous and as an announcement of a future bloody war by many citizens of Yugoslavia and, above all, Albanians and Croats. The author of the article undertook to analyze this speech in terms of phraseology.

Keywords: language of politics, Slobodan Milošević, Serbia, Anti-bureaucratic revolution, Newspeak

Słowa kluczowe: język polityki, Slobodan Milošević, Serbia, antybiurokratyczna rewolucja, nowomowa

\section{Wprowadzenie}

W roku 2019 minęła trzydziesta rocznica sławetnego przemówienia Slobodana Miloševicia wygłoszonego w dzień św. Wita (Vidovdan), 28 czerwca 1989 roku w jubileusz 600-lecia bitwy na Kosowym Polu.

Przemówienie to przez wielu obywateli Jugosławii, a przede wszystkim Albańczyków i Chorwatów, uznane zostało za złowieszcze i będące zapowiedzią przyszłej krwawej wojny. Jako szczególnie złowrogi przyjęto fragment wystąpienia odnoszący się do przy- 
szłych bitew: „Dzisiaj, sześć wieków później, znowu jesteśmy w bitach i przed bitwami. One nie są zbrojne, chociaż i takie nie są jeszcze wykluczone" ${ }^{\prime}$.

Znajdujemy tego ślady w późniejszych relacjach chorwackich i albańskich przywódców. Co ciekawe, kwestia tego fragmentu przemówienia była także podejmowana w procesie Miloševicia przed Międzynarodowym Trybunałem Karnym w Hadze. 1 października 2002 roku Geoffrey Nice, oskarżyciel Miloševicia, postawił świadkowi Stipe Mesiciowi pytanie, jakie wrażenie wywarło na ludziach przemówienie prezydenta Serbii wygłoszone na Gazimestanie? Wówczas to prezydent Chorwacji odpowiedział: „Po przemówieniu, jakie na Gazimestanie wygłosił Slobodan Milošević, było całkiem jasne, czego pragnie nowe kierownictwo Serbii. Tak więc obwieszczono i możliwość zbrojnych bitew. Powiedziano, aby wszyscy byli gotowi na ten lub tamten sposób prowadzenia walki, ale mówiono, że nie są wykluczone i zbrojne bitwy. To był pierwszy raz, że ktoś w Jugosławii wspomniał możliwość opcji wojennej, wariant pójścia na wojnę"2.

Natomiast Azem Vllasi, w latach 1986-1988 przewodniczący Związku Komunistów Kosowa (ZKK), wspominając po trzydziestu latach to przemówienie Miloševicia, przypisuje mu zapowiedź przyszłej wojny. Zdaniem albańskiego komunisty, likwidacja przez Miloševicia autonomii Albańczyków w Kosowie była preludium do krwawego rozpadu Jugosławii: ,[Milošević] na Gazimestanie przy okazji 600-lecia przegranej bitwy z Turkami na Kosowie świętował to, co siłą osiagnął w Kosowie. I przy tej okazji wypowiedział wojnę i innym w Jugosławii, którzy zamierzali stać na jego drodze, mówiąc: »Serbia znajduje sie przed bitwami, i nie są wykluczone i te zbrojne«. I dotrzymał tego, co obiecal"'.

\section{Kosowo i język „antybiurokratycznej rewolucji”}

Kosowo było miejscem, gdzie Milošević rozpoczął swoją drogę do przejęcia pełni władzy w Serbii (i stania się liderem dla większości Serbów). Niewątpliwie Milošević, wykorzystując do tego trudną sytuację Serbów w Kosowie, przeciwstawił się strategii wielkoalbańskiego nacjonalizmu ${ }^{4}$. Kosowscy Serbowie bardzo się wówczas uskarżali na to, że albańska większość - na skutek posiadanej dotychczas autonomii ${ }^{5}$, dopuszczała się w stosunku do nich licznych niegodziwości. Tutaj szczególnie piętnowano psychiczny i fizyczny stalking, przymusową ekspatriację, wykup ziemi oraz skrytobójstwa i przemoc seksualną ${ }^{6}$.

\footnotetext{
${ }^{1}$ S. Milošević, Prilog istoriji dvadesetog veka, Beograd 2008, s. 23-26; zob. D. Jović, Jugoslavija država koja je odumrla. Uspon, kriza i pad Kardeljeve Jugoslavije (1974-1990), Zagreb 2003, s. 460; P. Żurek, Stowenia w walce o niepodległość (1980-1992). Wyjść z cienia Jugosławii, Kraków 2019, s. 79.

${ }^{2}$ Proces Slobodana Miloševicia. (IT-02-54). Međunarodni krivični tribunal za bivšu Jugoslaviju. Transkripti. Przesłuchanie Stipe Mesicia, 1 października 2002. Fond za humanitarno pravo, s. 178-179.

${ }^{3}$ Azem Vlasi, Dan kada je Milošević objavio rat!, „Dnevni avaz”, 28.06.2019.

${ }^{4}$ D. Jović, op. cit., s. 380-417.

${ }^{5}$ O tym, jak Serbowie postrzegali autonomię Albańczyków, zob. M. Luković, Kryzys kosowski oczyma Serbów, Belgrad 2000, s. 66-73.

${ }^{6} \mathrm{O}$ oskarżeniach kosowskich Serbów w stosunku do Albańczyków zob.: M. Blagojević, R. Petrović, Seobe Srba i Crnogoraca sa Kosova i iz Metohije, Beograd 1989; Kosovski čvor. Drešiti ili seći?, ed. S. Popović, D. Janča, T. Petovar, Beograd 1990.
} 
W maju 1986 roku Milošević dzięki poparciu swojego dotychczasowego zwierzchnika, Ivana Stambolicia, został wybrany na przewodniczącego Związku Komunistów Serbii (ZKSR). Niemniej w szeregach partii istniała niemała opozycja co do jego kandydatury, dlatego też wybór Miloševicia poprzedzony został żarliwą akcją agitacyjną jego pryncypała, który sam przygotowywał się do objęcia stanowiska przewodniczącego Prezydium Serbii (prezydenta Serbii). Stambolić do kandydatury Miloševicia szczególnie przekonywał Azema Vllasiego, obiecując z nim lepszą i łatwiejszą współpracę7.

Początkowo Milošević praktycznie nie interesował się Kosowem, i nawet sam to doradzał Stamboliciowi - „Daj sobie spokój z okręgami, obierzmy kurs na Jugosławię”. Rzeczywiście do roku 1987 Kosowo było domeną Stambolicia, który tak naprawdę nie potrafił dać sobie rady z panującą tam trudną sytuacją ${ }^{9}$. Z jednej strony Albańczycy domagali się większych praw (hasło „Kosowo Republika”), z drugiej zaś Serbowie żądali od Belgradu zwiększenia ochrony. W tej ostatniej kwestii Stambolicia zaczęła przerastać sytuacja wynikająca z faktu, że kosowscy Serbowie przystąpili do organizowania się i zdecydowanego domagania od władz Serbii konkretnego poparcia. Tę radykalizację odczuł sam Stambolić w kwietniu 1986 roku podczas swojej wizyty w Kosowym Polu. Wówczas to próbował uspokajać demonstrujących Serbów utartymi sloganami, że „odpowiedzią na albański nacjonalizm nie może być serbski nacjonalizm”. Stambolić najwyraźniej jeszcze bardziej rozjuszył kosowskich Serbów, gdy stwierdził, że nie powinni szukać pomocy w Belgradzie, tylko ,załatwiać swoje problemy w kosowskim kierownictwie” (czyli u Albańczyków Vllasiego ${ }^{10}$. Innymi słowy, Stambolić zalecał kosowskim Serbom zachowanie status quo, co bardziej odpowiadało Albańczykom. Chociaż Stambolić wspomina, że jego ówczesne wystąpienie w Kosowym Polu zostało nagrodzone aplauzem ${ }^{11}$, to jednak stało się dla niego katastrofą polityczną. Azem Vllasi trafnie zauważa, że najbardziej niezadowolone z przemówienia Stambolicia były „mroczne nacjonalistyczne umysły SANU”

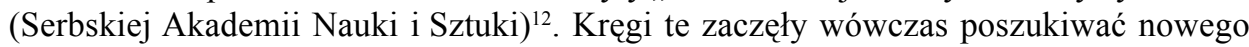
serbskiego lidera.

Kiedy w kwietniu 1987 roku ponownie wybuchły protesty Serbów w Kosowym Polu, Stambolić, obawiając się kolejnej kompromitacji, wysłał tam Miloševicia. Jeszcze przed wyjazdem serbski przewodniczący skonsultował ze Stamboliciem treść swojego wystąienia. Prezydent Serbii zalecał mu umiarkowanie i nieuleganie emocjom. („Lej zimną wodę”, „Uważaj, aby zachować chłodną głowę”) ${ }^{13}$.

Na spotkanie z kosowskim aktywem Milošević przybył do Domu Kultury Kosowego Pola 24 kwietnia po południu. Jednak jeszcze przed jego rozpoczęciem zaczęły do niego

\footnotetext{
${ }^{7}$ K. Nikolić, Kako je Slobodan Milošević izabran za vođu srpskih komunista (II), „Istorija 20 veka”, 2/2006, s. 105-121; Azem Vllasi w swoich wspomnieniach pisze, że Stambolić był wówczas zachwycony Miloševiciem i gorąco go rekomendował słowami „Najlepszą zaletą Slobodanową jest to, że nie jest nacjonalistą. A nawet on jest bez mała antynacjonalistą, zob. A. Vllasi, Kosovo, početak raspada, Sarajevo 2016, s. 312.

${ }^{8}$ I. Stambolić, Put u bespuće, Beograd 1995, s. 165.

${ }^{9}$ K. Nikolić, ,, Niko ne sme da vas bije”. Slobodan Milošević u Kosovu Polju 24-25. april 1987, Beograd 2006, s. 88.

${ }^{10}$ A. Vllasi, op. cit., s. 314; zob. K. Nikolić, ,, Niko ne sme da vas bije”..., s. $61 \mathrm{n}$.

${ }^{11}$ I. Stambolić, op. cit., s. 166.

${ }^{12}$ A. Vllasi, op. cit., s. 314; W swoich wspomnieniach Stambolić sugeruje, że do jego upadku przyczyniły się intelektualno-naukowe kręgi SANU, zob. I. Stambolić, op. cit., s. 117-131.

${ }^{13}$ I. Stambolić, op. cit., s. 165-167.
} 
docierać informacje, że wielu delegatów serbskich nie zostało wpuszczonych, a przed budynkiem doszło do starcia serbskich demonstrantów z milicją. (Wówczas składającą się głównie z Albańczyków). Przewodniczący ZKSR dał się wtedy ponieść emocjom i wyszedł przed budynek. Tam dotarły do niego okrzyki demonstrantów „Biją nas”. Milošević wypowiedział w kierunku kosowskich Serbów swoje słynne słowa: „Nikomu nie wolno was bić!”. Następnie po jego interwencji do Domu Kultury zostali wpuszczeni przedstawiciele demonstrantów i rozpoczęła się dyskusja ${ }^{14}$. W jej trakcie kosowscy Serbowie skarżyli się, że ich albańscy sąsiedzi czynią ich życie nieznośnym ${ }^{15}$. Po dyskusji głos zabrał Milošević. Zgodnie z instrukcją serbski przewodniczący, używając klasycznej frazeologii jugosłowiańskiego komunizmu, wygłosił przemówienie w duchu ,braterstwa i jedności” oraz marksistowskiego internacjonalizmu. Jedynie ogólnikowo odniósł się do zagrożeń separatyzmem i nacjonalizmem, widząc w tym przede wszystkim kontrrewolucję. Niemniej zapewne pod wpływem atmosfery, mgliście zaczął mówić o ,zjawisku wysiedlania Serbów i Czarnogórców”, czego przyczyn upatrywał bardziej w kwestiach ekonomicznych i politycznych. Tutaj jednak ostrożnie zwrócił uwagę na fakt, że zjawisko to odbywa się „,często zwyczajnie pod presją fizyczną”. Nie wskazał jednak, kto się tego dopuszcza. Mówił o Kosowie jako wspólnym obszarze egzystencji Albańczyków oraz Serbów i Czarnogórców. Milošević, próbując uspokoić sytuację, obiecywał mieszkańcom Kosowa poprawę życia materialnego, wzrost inwestycji i więcej miejsc pracy. Wysiedlonym Serbom i Czarnogórcom gwarantował prawo do powrotu. Przewodniczący ZKSR nie ukrywał, że to właśnie komuniści powinni w duchu jugosłowiańskiego systemu socjalistycznego rozwiązać problemy Kosowa ${ }^{16}$.

Milošević z jednej strony dostrzegał rosnącą siłę albańskiego nacjonalizmu i pogarszającą się sytuację Serbów w Kosowie, z drugiej zaś w ich poparciu widział drogę do realizacji swoich ambicji politycznych. Tym bardziej że wizyta Miloševicia w Kosowym Polu została zapamiętana dzięki jego stwierdzeniu „Nikomu nie wolno was bić!’. I mimo że Milošević zdanie to wypowiedział w zamieszaniu, to jednak medialnie zostało ono odpowiednio wyeksponowane i było bardzo dobrze przyjęte przez serbskie środowiska nacjonalistyczne. W rezultacie wypowiedź ta spotęgowała albański i serbski nacjonalizm, co jeszcze bardziej nakręciło spiralę nienawiści. Później słowa te stały się symbolem prowadzonej w różnych częściach Jugosławii polityki propagowania rzekomego ,zagrożenia Serbów" przez inne narody.

Już w lipcu 1989 roku na VI plenum KC ZKSR Milošević postawił przed partią „zadanie" roztoczenia opieki nad Serbami w Kosowie (zapewnienia bezpieczeństwa wewnętrznego i umożliwienia prawa do powrotu $)^{17}$. Dodatkowo Milošević w imię obrony Serbów

\footnotetext{
${ }^{14}$ Intervju: Miroslav Šolević, „Vreme”, nr 454, 18 września 1999; Proces Slobodana Miloševicia. (IT-02-54). Međunarodni krivični tribunal za bivšu Jugoslaviju. Transkripti. Przesłuchanie Mitara Balevicia, 9 lutego 2005. Fond za humanitarno pravo, s. 416-499; A. Vllasi, op.cit., s. 328-329. Według Vllasiego milicja wcale nie biła demonstrantów.

${ }^{15}$ Vllasi twierdził, że wizyta Miloševicia, jak i tok dyskusji, w tym „kłamliwe” skargi Serbów wcześniej zostały zainscenizowane przez lokalnych serbskich ekstremistów i ludzi z Belgradu. Natomiast sam Milošević tak wspominał to spotkanie: ,Ja wówczas pierwszy raz usłyszałem tę frazę »etnicznie czyste«. Wówczas to było Kosowo. Ich (Albańczyków) celem było czyste etnicznie Kosowo. Ludzie (Serbowie) byli zabijani, nawet groby były rozkopywane, palone monastyry i sady, pola. Rozpoczął się exodus Serbów z Kosowa”, zob. serial BBC „The Death of Yugoslavia” (odc. 1, 1995).

${ }^{16} \mathrm{~S}$. Milošević, Godine raspleta, Beograd 1989, s. 140-146.

${ }^{17}$ Ibidem, s. $158-161$.
} 
w Kosowie zaczął rozbudzać serbski nacjonalizm, doprowadzając w pierwszym rzędzie do konfliktu ze swoim długoletnim pryncypałem, Ivanem Stamboliciem. Do decydującego ich starcia doszło na VIII plenum KC ZKSR, które odbyło się w dniach 23-24 września 1987 roku i zakończyło spektakularnym zwycięstwem Miloševicia, a w konsekwencji złożeniem przez Stambolicia dymisji ze stanowiska przewodniczącego Prezydium Serbii (prezydenta Serbii). Nowym prezydentem Serbii został Petar Gračanin, który był ściśle związany z Miloševiciem. Tym samym w karierze Miloševicia rozpoczął się nowy etap tzw. ,,antybiurokratycznej rewolucji”"18.

W pierwszym rzędzie polegała ona na lansowaniu przez serbskie media Miloševicia jako opatrznościowego i nowoczesnego wodza narodu. W konsekwencji doprowadziło to do wymiany nielojalnych w stosunku do serbskiego lidera ludzi na każdym szczeblu hierarchii kierownictwa ZKSR ${ }^{19}$. Milošević kreowany był przede wszystkim jako ten, który doprowadzi naród serbski do ,,jedności”. Tym samym marginalizowano najbardziej fundamentalną zasadę funkcjonowania titowskiej Jugosławii, czyli „,braterstwa i jedności”, tj. ,jedności” SFRJ i wszystkich narodów tego państwa. Oczywiście ,jedność” Serbów (jak i Serbii oraz ZKSR) początkowo odnosiła się tylko do granic Socjalistycznej Republiki Serbii, niemniej z czasem została ukierunkowana na inne obszary Jugosławii ${ }^{20}$.

Zgodnie z duchem nowej polityki odsunięcie od władzy ekipy Stambolicia określone zostało jako „Pożegnanie z brakiem jedności w kierownictwie Serbii”"21. W nowej konstelacji politycznej ,jedność” miała polegać na konsolidacji nowoczesnego narodu serbskiego. Jako pierwsza medialnie proces ten zainicjowała Mirjana Mira Marković, żona Slobodana Miloševicia, będąca profesorem socjologii i jednocześnie główną polityczną mentorką Miloševicia. Mira Marković umiejętnie potrafiła wykorzystać swoją wiedzę naukową oraz rodzinne koneksje, aby realizować i własne ambicje polityczne. Nieformalnie sprawowała ona funkcję kogoś w rodzaju osobistej spin doktorki serbskiego lidera ${ }^{22}$.

Propagandową kulminacją procesu budowy ,,jedności” był mityng zwolenników Miloševicia, jaki miał miejsce 19 listopada 1988 roku na belgradzkim Ušću. Był to jeden z największych mityngów ,„antybiurokratycznej rewolucji”. Krótko przed przemówieniem Miloševicia do zgromadzonego tłumu zwrócił się oddany mu dziennikarz Radio-Telewizji Belgrad, poeta Milovan Vitezović: „Szanowny narodzie, nasza historia zapamięta ten rok jako rok, w którym wydarzył się nam naród”. Od tego momentu w serbskim języku polityki utarł się termin „wydarzenia narodu”, stający się synonimem miloševiciowskich mi-

${ }^{18}$ B. Jović, Knjiga o Miloševiću, Beograd 2001, s. 31-40; D. Jović, Osma sednica: uzroci, značaj, interpretacije, [w:] Slobodan Milošević - put ka vlasti (Osma sednica CK SKS), Beograd 2008, s. 33-67. Zob. M. Korzeniewska-Wiszniewska, Serbia pod rzqdami Slobodana Miloševicia. Serbska polityka wobec rozpadu Jugosławii w latach dziewięćdziesiatych XX w., Kraków 2008, s. 70-71. Zob. M.J. Zacharias, Komunizm, federacja, nacjonalizmy. System władzy w Jugostawii 1943-1991. Powstanie, przekształcenia, rozkład, Warszawa 2004, s. 439.

${ }^{19}$ D. Jović, Jugoslavija - država koja je odumrla ..., s. 414-426.

${ }^{20}$ Zob. P. Żurek, Styl i frazeologia języka polityki przemówień Slobodana Miloševicia z lat 1984-89, [w:] Rozwarstwienia stylistyczne języków słowiańskich. Style funkcjonalne i stylizacje literackie, Katowice 1996, s. $151-156$.

${ }^{21}$ Zob. S. Milošević, Godine..., s. 170.

${ }^{22}$ O. Milosavljević, Antibirokratska revolucija 1987-89, [w:] Dijalog povjesničara istoričara, t. VIII, Zagreb, 2004, s. 323-324. 
tyngów i symbolem ,,antybiurokratycznej rewolucji”23. Przemówienie Miloševicia na Ušću zapoczątkowało w jego języku polityki eksponowanie kwestii ,zatrzymania terroru w Kosowie" i zacieśnienia więzi tego regionu z Belgradem. Nieprzypadkowo też serbski lider osiągnięcie wskazanego celu w tym przemówieniu określił słowem „,bitwa”: „Bitwę o Kosowo wygramy bez względu na przeszkody, które nam stawiają w kraju i poza nim. [...]. Zwyciężymy pomimo tego, że obecnie, jak niegdyś, jednoczą się przeciwko Serbii jej zewnętrzni i wewnętrzni wrogowie. Mamy dla nich wiadomość, że wcale nie jesteśmy strachliwi, że do każdej bitwy przystępujemy z zamiarem jej wygrania...”. W przemówieniu wygłoszonym na Ušću Milošević słowa „bitwa” użył siedem razy ${ }^{24}$. Pod względem frazeologicznym widać w tym wystąpieniu, jak nadużywany w komunistycznej propagandzie wyraz „bój” został zastąpiony słowem „bitwa”. Milošević jako komunistyczny aparatczyk odszedł w tym przemówieniu od rozumianego w kontekście przesłania tekstu Międzynarodówki pojęcia „,boju” („Bój to jest nasz ostatni”) i nieprzypadkowo użył nowego terminu - „bitwa”. W nowomowie ,antybiurokratycznej rewolucji” słowo „bitwa” świadomie koresponduje z bitwą na Kosowym Polu i stanowi element nowej polityki. Wówczas jeszcze skupionej na ograniczeniu autonomii Albańczyków w Kosowie.

Następnie krokiem politycznym Miloševicia było rozpoczęcie formowania ,jedności” wszystkich Serbów. Tutaj serbski lider kształtował swój wizerunek polityczny jako obrońcy praw Serbów na drodze likwidacji tak zwanej ,niesprawiedliwości”. Chodziło przede wszystkim o to, że Serbowie jako największy naród socjalistycznej Jugosławii czuli się pokrzywdzeni terytorialnie. Po pierwsze, tylko ich republika ma w swoich strukturach okręgi autonomiczne, które w wielu kwestiach mają uprawnienia równe republikom. Po drugie, Serbowie - stanowiąc znaczny procent mieszkańców republik Chorwacji oraz Bośni i Hercegowiny - nie posiadali tam swojej autonomii terytorialnej. Początkowo Milošević starał się załatwić te kwestie poprzez wprowadzenie zmian w konstytucji Serbii i Jugosławii: „Celem zmian konstytucyjnych jest zlikwidowanie tej niesprawiedliwości, jaka w porównaniu z innymi republikami spotkała Serbię w ramach Jugosławii" 25 .

Manewr ten miał szanse się powieść jedynie w ramach Serbii. I tak już na początku roku 1989 na forum Związku Komunistów Jugosławii (ZKJ) Milošević planowane ograniczenie autonomii Wojwodiny i Kosowa również zdefiniował jako ,jedność, czyli „homogenizację” niemającą podłoża narodowościowego - „Jedność Serbii nie służy przeszłości, lecz teraźniejszości i przyszłości”. Serbski lider - zapewne w kontekście stawianych przez kosowskich Serbów w stosunku do Albańczyków zarzutów o przemoc - stwierdził: „Jedność nie zrodziła się w Serbii z nienawiści do niewinnych ludzi, ale z solidarności z ofiarami przemocy" ${ }^{\prime 26}$.

Najbardziej widocznym elementem, a zarazem medialnym show ,,antybiurokratycznej rewolucji” były mityngi, które odbywały się w latach 1988-1991. Ich bazowym organizatorem był specjalnie do tego powołany Komitet do spraw protestów i solidarności z kosowskimi Serbami i Czarnogórcami. Mityngi były profesjonalnie zorganizowanymi i doskonale sterowanymi demonstracjami zwolenników Miloševicia. Zgromadzenia te ukie-

${ }^{23}$ I. Čolović, Sve je počelo u Srbiji?, [w:] Zid je mrtav, živeli zidovi!, Beograd 2009, s. 39-40. Zob. N. Popov, Serbski dramat. Od faszystowskiego populizmu do Miloševicia, Warszawa 1994, s. 54.

${ }^{24}$ S. Milošević, Godine ..., s. 274-277.

${ }^{25}$ Ibidem, s. 342.

${ }^{26}$ Ibidem, s. 334. 
runkowane były przeciwko wrogom politycznym Miloševicia i głównym ich zadaniem było destabilizowanie obszarów nielojalnych wobec serbskiego lidera. Dodatkowo mityngi przyciagały różne radykalne grupy nacjonalistyczne, co powodowało, iż Milošević jednocześnie przejmował kontrolę nad tego typu tendencjami i chcąc utrzymać władzę, stawał się coraz bardziej radykalnym nacjonalistą ${ }^{27}$. Dla Prezydium SFRJ sytuacja stawała się groźna, kiedy mityngi zaczęły być organizowane poza granicami Serbii i jej okręgów autonomicznych ${ }^{28} .14$ stycznia 1989 roku mityngi wymusiły dymisję dotychczasowego kierownictwa Czarnogóry ${ }^{29}$. Z kolei 28 lutego odbył się w Belgradzie największy i najburzliwszy z mityngów ,antybiurokratycznej rewolucji”. Głównym żądaniem rozszalałego tłumu było aresztowanie lidera kosowskich komunistów Azema Vllasiego ${ }^{30}$. Mityng ten zakończył się zapewne dobrze wyreżyserowaną deklaracją Miloševicia, iż organizatorzy strajku albańskich górników w Kosowie zostaną aresztowani. Zgodnie z tą obietnicą na początku marca Azem Vllasi trafił do więzienia ${ }^{31}$.

Tego samego dnia co wspomniany mityng w Belgradzie odbył się w Kninie mityng solidarności chorwackich Serbów z rodakami w Kosowie. Zgromadzeni wyrażali także swoje poparcie dla polityki Miloševicia ${ }^{32}$. Na domiar złego, 25 marca planowano zorganizować mityng w Lublanie, jednak nie doszedł on do skutku ${ }^{33}$. Mimo to 28 marca 1989 roku Miloševiciowi udało się doprowadzić do uchwalenia przez skupsztynę Serbii poprawek do konstytucji republiki, które poważnie ograniczały autonomię Kosowa i Wojwodiny. Dzięki temu sprytnemu manewrowi Milošević zyskał dla Serbii dwa dodatkowe głosy w Prezydium SFRJ i stworzył w nim tzw. serbski blok ${ }^{34}$. Wzmocnieniu uległa także pozycja Miloševicia, który 8 maja objął stanowisko prezydenta Serbii w miejsce Gračanina ${ }^{35}$.

\section{Jubileusz 600-lecia bitwy na Kosowym Polu}

28 czerwca 1989 roku Slobodan Milošević nieprzypadkowo wygłosił przemówienie w kompleksie memorialnym upamiętniającym bitwę na Kosowym Polu, zwanym Gazimestan (miejsce bohaterów - miejsce głównego starcia) ${ }^{36}$. Przypomnijmy, iż w kontekście opartej na epice ludowej serbskiej mitologii narodowej miejsce to stanowiło centralny punkt tradycji Serbów, zasadzającej się na syntagmie „Kosowskiego Przykazania” („Kosovski zavet”) - wezwania do ,pomszczenia Kosowa” i odbudowy potęgi Serbii (carstwa) ${ }^{37}$.

W micie kosowskim zawarta została serbska tradycja „niezgody” („nesloga”) oraz „zdrady” (,izdaja”) i „,bohaterstwa” (,junaštva”). Dzięki serbskiej epice ludowej te legen-

${ }^{27}$ O. Milosavljević, op.cit., s. 319-336; D. Jović, Jugoslavija - država koja je odumrla ..., s. 419-426.

${ }^{28}$ R. Dizdarević, Od smrti Tita do smrti Jugoslavije, Sarajevo 2000, s. 189-220.

${ }^{29}$ R. Šćekić, „Događanje naroda” u Crnoj gori. Političko-propagandni okvir, „Matica”, wiosna 2011, s. 312-319.

${ }^{30}$ A. Vllasi, op.cit., s. $437-439$.

${ }^{31}$ D. Jović, op.cit., s. 458-459.

${ }^{32}$ N. Barić, Srpska pobuna u Hrvatskoj 1990-1995, Zagreb 2005, s. 42.

${ }^{33}$ B. Repe, Jutri je nov dan. Slovenci in razpad Jugoslavije, Ljubljana 2002, s. 115-116.

${ }^{34}$ B. Jović, Knjiga o Miloševiću, Beograd 2001, s. 41-51.

${ }^{35}$ „Borba”, 9 maja 1989, s. 1.

${ }^{36}$ Đ. Jevtić, Bitka za Kosovo. Šest vekova posle, t. I, Beograd 1995, s. 40-227.

${ }^{37}$ Ž. Gavrilović, Kosovski zavet srpskog naroda, Beograd 1989. 
darne tradycje były głęboko zakorzenione w świadomości dziejowej Serbów. Opiewany przez guślarzy w epoce niewoli tureckiej epos rycerski zbudował w świadomości niepiśmiennego ludu idealistyczny obraz przebiegu tej przegranej dla Serbów bitwy ${ }^{38}$.

Wbrew prawdzie historycznej serbska epika ludowa o zdradę i w efekcie spowodowanie klęski w bitwie oskarża Vuka Brankovicia. Mówi ona także o tym, że w boju zginęła cała szlachta serbska, a legendarny królewicz Marko spóźnił się na bitwę kosowską̧ ${ }^{39}$. W tak epicko przedstawioną tradycję ,niezgody” i „zdrady” do dzisiaj wierzą Serbowie. Rzeczywistość była jednak inna. Tak naprawdę w trakcie bitwy na Kosowym Polu doszło do powszechnego buntu rycerstwa serbskiego przeciwko ,samodzierżawcy wszystkich Serbów”, księciu Lazarowi. Był on wywołany „niezgodą” i ,zdradą” wasali oraz sojuszników serbskiego władcy. Książę Lazar dostał się do niewoli i został natychmiast ścięty przez Turków razem z tymi, którzy go zdradzili ${ }^{40}$. Natomiast tradycja „bohaterstwa” odnosi się nie tyle do księcia Lazara i poległych w bitwie serbskich rycerzy, ale przede wszystkim do postaci Miloša Obilicia, rycerza serbskiego, który w trakcie bitwy skrytobójczo zamordował Murada, sułtana tureckiego ${ }^{41}$.

W tradycji serbskiej mit kosowski został mocno rozbudowany w epopei Górski wieniec, napisanej przez czarnogórskiego władykę Petara II Petrovicia - Njegoša. Utwór ten powstał w 1846 roku, czyli w okresie kiedy to Serbowie stopniowo zaczęli odbudowywać swoją państwowość. Nieprzypadkowo też treść Górskiego wieńca przede wszystkim eksponuje kosowskie „bohaterstwo”, a jego główną postacią jest Miloš Obilićc ${ }^{42}$. O wpływie, jaki ten utwór wywarł na Serbów, może świadczyć fakt, że Gavrilo Princip znał Górski wieniec na pamięć i kiedy w Vidovdan 28 czerwca 1914 roku w Sarajewie dokonywał zamachu na arcyksięcia Ferdynanda zainspirowany był czynem Miloša Obilicia (mit tyranobójstwa $)^{43}$.

Mira Marković w swoich opublikowanych wspomnieniach pisze, że „korekta wieloletniej historycznej niesprawiedliwości w stosunku do Serbii w kontekście okręgów autonomicznych i zahamowania albańskiego terroru w Kosowie zbiegła się z obchodami 600-lecia bitwy kosowskiej”. Ponadto prezydentowa staranie podkreśla, że jej mąż był już wtedy „formalnie” uznanym „,liderem serbskiego narodu”. Zdaniem Miry Marković, mające miejsce 28 czerwca 1989 roku na Kosowym Polu obchody tej bitwy miały na celu nie tylko oddanie hołdu jej „,bohaterom”, ale i ,wysłuchanie przemówienia Slobodana Miloševicia”. Dlatego też wówczas „odbyło się największe zgromadzenie serbskiego narodu,

\footnotetext{
${ }^{38}$ Por. B. Zieliński, Serbska powieść historyczna, Poznań 1998, s. 156-172.

${ }^{39}$ Zob. Królewicz Marko. Narodowe pieśni serbskie, przekład R. Zmorski, Warszawa 1859; Pieśni narodowe serbskie. Bój na Kosowem polu (Lazarica), przekład R. Zmorski, Warszawa-Kraków 1913. O przebiegu bitwy na Kosowym Polu zob. N. Malcolm, Kosovo. A Short History, New York 1998, s. 58-80; I. Czamańska, J. Leśny, Bitwa na Kosowym Polu 1389, Poznań 2015.

${ }^{40}$ Pamiętniki Janczara czyli Kronika Turecka Konstantego z Ostrowicy napisana między r. 1496 a 1501, Kraków 1912, s. 40-41; M. Orbini, Kraljevstvo Slavena, Zagreb 1999, s. 379-380. O konfliktach wewnętrznych w rozbitej na dzielnice XIV-wiecznej Serbii zob. R. Mihaljčić, Lazar Hrebeljanović. Istorija, kult, predanje, Beograd 2001, s. 78-132.

${ }^{41}$ Zob. R. Mihaljčić, Junaci kosovske legende, Beograd 1989.

${ }^{42}$ J. Rapacka, Godzina Herdera, Warszawa 1995, s. 122-124; B. Aleksić, Kosovo i kosovski zavjet u Njegoševom književnom djelu, „Godišnjak Fakulteta za kulturu i medije”, nr 9, R. IX, Beograd, 2017, s. 316-318. Por. D. Gil, Prawostawie. Historia. Naród. Miejsce kultury duchowej w serbskiej tradycji i wspótczesności, Kraków 2005, s. 119-123.

${ }^{43}$ V. Dedijer, Sarajewo 1914, t. II, Łódź 1984, s. 27-43.
} 
od kiedy ten naród istnieje”. Według niej wygłoszone tam przemówienie Miloševicia było „apoteozą pokoju, równoprawności, zgody i rozwoju”. W podtekście swoich wspomnień Mira Marković wyjawia i faktyczny cel tego wystąpienia jej męża - pokojowe zamanifestowanie ,zgody” oraz ,jedności serbskiego narodu w postanowieniu zachowania Kosowa"44. Slobodan Milošević zdawał sobie już wtedy sprawę, że Serbia wchodzi w okres zachodzących w państwach komunistycznych zmian demokratycznych, dlatego on, jak i jego zaplecze polityczne przygotowywali się już wtedy do pierwszych wolnych wyborów (grudzień 1990). Serbski prezydent chciał się tym samym pokazać światu nie jako komunistyczny satrapa i gnębiciel Albańczyków, ale jako otwarty na dialog demokrata; z tego powodu przemówienie wygłoszone w Vidovdan na Gazimestanie było początkiem kampanii wyborczej Miloševicia, ukierunkowanej na wolne wybory ${ }^{45}$. Tutaj serbski historyk Kosta Nikolić słusznie skonstatował, że „,wielopartyjny system w Serbii powstał z miloševiciowskiej populistycznej »antybiurokratycznej rewolucji «"46.

Zorganizowane w 1989 roku obchody 600-lecia bitwy kosowskiej były niczym innym jak finezyjnie zainscenizowanym jednym z mityngów ,antybiurokratycznej rewolucji”. Dzięki tej już dobrze rozpędzonej machinie propagandowej Milošević miał już takie poparcie społeczne, które pozwalało mu stanąć w szranki demokratycznych wyborów. Mityng na Gazimestanie był tego jedynie zwieńczeniem i potwierdzeniem.

\section{Konstrukcja przemówienia Miloševicia - Vidovdan 28 czerwca 1989 r. $^{47}$}

Milošević już w pierwszym zdaniu swojego wystąpienia zastosował chwyt retoryczny nazywany magicznością języka polityki, określając Kosowo jako „serce Serbii”48. Od tego momentu slogan „Kosowo jest sercem Serbii” („Kosovo je srce Srbije”) stał się szeroko rozpropagowanym hasłem sprzeciwu wobec albańskich planów niepodległości Kosowa. Według serbskiego antropologa Ivana Čolovicia, na Gazimestanie Milošević, lansując ten slogan, nawiązywał do mitu kosowskiego. Z jednej strony wskazywał Serbom święte miejsce, z drugiej „mówił o Serbach, którzy ponoszą ofiarę dla Europy”49.

Odniesienie do mitu kosowskiego widoczne jest w samej kompozycji przemówienia wygłoszonego przez Miloševicia na Gazimestanie. Mianowicie budowa przemówienia oparta została na dwóch układach frazeologicznych: zestawieniu sytuacji w Serbii

\footnotetext{
${ }^{44}$ M. Marković, Bilo je to ovako, t. I, Beograd 2015, s. 303.

${ }^{45}$ B. Jović, Knjiga o Miloševiću, Beograd 2001, s. 59-61; R. Tomas, Srbija pod Miloševićem. Politika devedesetih, Beograd 2002, s. 63-86.

${ }^{46}$ K. Nikolić, Obnavljanje parlamentarnog poretka u Srbiji 1990, „Tokovi istorije “, nr 2, 2011, s. 134.

${ }^{47}$ Analizę tekstu przemówienia Miloševicia z 28 czerwca 1989 roku oparto na wydaniu: S. Milošević, Prilog istoriji dvadesetog veka, Beograd 2008, s. 23-26, oraz zapisie transmisji telewizyjnej: Przemówienie Slobodana Miloševicia na Gazimestanie z 28 czerwca 1989 r., https:/www.youtube.com/watch?v=vdU6ngDhrAA, (dostęp: 05.01.2020).

${ }^{48} \mathrm{~W}$ wypowiedzi dla dokumentarnego serialu BBC - „The Death of Yugoslavia” (odc. 1, 1995) Milošević tłumaczył: „Kosowo nie jest zwyczajną częścią Serbii. Kosowo jest po prostu sercem Serbii. Cała nasza historia jest na Kosowie, wszystkie nasze monastyry są na Kosowie".

${ }^{49}$ O. Karabeg, Kosovski mit kamen o vratu Srbije, wywiad ze Svetlaną Slapšak i Ivanem Čoloviciem dla Radia Wolna Europa, https:/www.slobodnaevropa.org/a/most_kosovo_mit/1620087.html, (dostęp: 05.01.2020).
} 
w roku 1389 z tą obecną, w 1989 oraz grze słów: „niezgoda” (,nesloga”) - „zgoda” (,,sloga”) i ,zdrada” (,izdaja”) - „bohaterstwo” (,junaštvo”).

\section{A. Zestawienie: Serbia 1389 - Serbia 1989}

Serbski prezydent wywołuje to zestawienie już w czwartym zdaniu, stawiając pytanie: „z czym wyjdziecie przed Miłosza” (,sa čim ćemo pred Miloša”). Wśród Serbów pytanie to stawiane jest na Vidovdan. Dokładnie jest ono cytatem z epopei Górski wieniec Petara II Petrovicia Njegoša ${ }^{50}$. Jak wspominaliśmy już wcześniej, w dziele tym w oparciu o postać Miloša Obilicia rozbudowano mit kosowski ${ }^{51}$. Pytanie „z czym wyjdziecie przed Miłosza” odnosi się do „Kosowskiego Przykazania”. Innymi słowy, pytanie to wymusza od współczesnych odpowiedź, którą potomni są winni Obiliciowi: Co zrobiliście dla dobra Serbii?

Zgodnie z tym zwyczajem Milošević w przemówieniu odpowiada na to pytanie i przedstawia, co osiągnęła Serbia w 1989 roku. Tutaj serbski prezydent, wprowadzając w temat, wskazał, że nieprzypadkowo w roku obchodów 600-lecia bitwy na Kosowym Polu Serbia „odnowiła swoją państwową, narodową i duchową integralność”. Oczywiście w podtekście tego stwierdzenia ukryta jest aluzja do ograniczenia autonomii Albańczyków w Kosowie. Następnie Milošević, odpowiadając już na pytanie, zwraca uwagę, że Serbia „właśnie w tym 1989 roku odzyskała swoje państwo". Stwierdzenie to jest o tyle dziwne, że Serbia była wtedy ciągle republiką jugosłowiańską, a nie niepodległym państwem. Tym bardziej że serbski prezydent w stosunku do Serbii dwukrotnie używa terminu ,republika”. Zaznaczając, że: „Serbia jest dzisiaj jednolita, równoprawna z innymi republikami” („Srbija je danas jedinstvena, ravnopravna sa drugim republikama”). Oczywiście w stwierdzeniu tym zawarta jest kolejna aluzja odnosząca się do faktu, że w pozostałych republikach jugosłowiańskich inne narody nie mają autonomii. Milošević, idąc dalej w odpowiedzi na postawione pytanie, obiecuje Serbom świetlaną przyszłość, dobrobyt i demokrację. Zapowiada prosperity Serbii w cywilizacji XXI wieku. Niemniej tutaj serbski lider stawia jeden warunek, a mianowicie zwycięstwo w nadchodzących „,bitwach”.

\section{B. Gra słów: „niezgoda” - „zgoda” i „zdrada” - „bohaterstwo"}

Zdaniem Miloševicia, aby wygrać tę bitwę/te bitwy, Serbom potrzebne jest „,bohaterstwo”. Serbski prezydent na Gazimestanie słowo „bohaterstwo” wymienia pięć razy. Milošević, nawiązując do mitu kosowskiego, zwraca uwagę, że istnieją trzy „symbole” bitwy na Kosowym Polu: „bohaterstwo”, „zdrada” i „niezgoda”. Nieprzypadkowo też słowa „bohaterstwo” pierwszy raz używa w zestawieniu ze słowem „zdrada”, które również w przemówieniu pojawia się pięć razy. Lider Serbii jednak najczęściej, bo aż sześć razy, używa wyrazu ,niezgoda” i to przede wszystkim w tym właśnie zjawisku widzi największe zagrożenie. Dlatego też „odnowioną zgodę” narodową uznał za główny warunek pomyśl-

\footnotetext{
${ }^{50}$ Wersję polską sloganu podaję za: Petar Njegoš, Wybór pism, thum. H. Batowski, Wrocław-Kraków 1958, s. 20 .

${ }^{51}$ I. Andrić, Njegoš jako tragiczny bohater kosowskiej idei, [w:] We własnych oczach. XX-wieczny esej zachodnio- i potudniowostowiański, red. H. Janaszek-Ivaničkowa, Warszawa 1977, s. 219.
} 
nego rozwoju Serbów i Serbii. Milošević, nawołując do „zgody”, nawiązywał jednocześnie do magicznego dla Serbów sloganu: „Tylko zgoda Serbów ratuje” („Samo Sloga Srbina Spasava"). Genezę tego zawołania doszukuje się w historii godła Serbii - symbolice krzyża świętego Sawy (cztery skrzydła symbolizujące skrót SSSS). Już w czasach nowożytnych utarła się nazwa „szlachetny krzyż” (,,časni krst”) ${ }^{52}$. Należy tutaj zaznaczyć, że nad zbudowaną mównicą z której przemawiał Milošević na Gazimestanie, widniał ogromny złoty ,szlachetny krzyż”.

Oczywiście prezydent Serbii „zgodę” rozumiał jako zjednoczenie Serbów pod sztandarami swojej polityki, jako tej jedynie słusznej i dobrej. W następnych latach wraz z postępującym kryzysem ekonomicznym i przegranymi wojnami Milošević często będzie oskarżał o „zdradę” opozycję i niezadowolonych z jego polityki obywateli. Tutaj wyjątkowo przesycone jest oskarżeniami o „zdradę” przemówienie Miloševicia wygłoszone na ostatnim jego mityngu w Berane (Czarnogóra), 20 września 2000 roku. Przemawiający dodatkowo przyklejał wówczas rzekomym „zdrajcom” obelżywe etykietki typu: złodzieje, łapówkarze, tchórze, lizusy, hieny ${ }^{53}$.

Na Gazimestanie Milošević słowa ,zgoda” użył aż pięć razy, i to nie tylko w kontekście Serbii, ale także przyszłości Jugosławii. Zresztą tej kwestii serbski lider poświęca niemało miejsca w swoim przemówieniu. Jego zdaniem Jugosławia „,może przetrwać pod warunkiem całkowitej równoprawności wszystkich nacji, które w niej żyją". Co ciekawe, wyrazy „równoprawność”, „równoprawny” są tutaj wymieniane tylko w kontekście jugosłowiańskim. Poza tym Milošević nieprzypadkowo zwrócił tu uwagę na zaistniałe wówczas w Jugosławii zjawisko ,zagrożenia jednej nacji od drugiej”.

Przypomnijmy, że w latach 1991-1992, w chwili wybuchu wojen w Chorwacji oraz Bośni i Hercegowinie (BiH), to właśnie Serbowie uskarżali się na „zagrożenie” ze strony swoich sąsiadów. Obsesja Serbów na punkcie ,zagrożenia” była efektem etnicznej polityki kosowskich Albańczyków, jaką ci prowadzili w okresie autonomii. Dlatego też z chwilą rozpadu Jugosławii serbskie kręgi nacjonalistyczne, mając na uwadze tragiczne doświadczenia kosowskie, obawiały się, że oderwana od Belgradu społeczność serbska w Chorwacji oraz BiH poddana zostanie prześladowaniom ze strony większości.

Wsłuchując się w wypowiedziane przez Miloševicia na Kosowym Polu słowa o „zagrożeniu”, nie sposób uniknąć tutaj skojarzenia z treścią Memorandum Serbskiej Akademii Nauki i Sztuki (SANU) z 1986 roku$^{54}$. Zresztą w wystąpieniu serbskiego prezydenta można znaleźć więcej stwierdzeń nawiązujących do tego dokumentu. Szczególnie wpisuje się w ten wątek aluzja Miloševicia, że Serbowie nie potrafili wykorzystać faktu, iż to oni byli głównymi bojownikami o socjalistyczną Jugosławię. Serbski prezydent taki stan rzeczy złożył na karb idealizmu i naiwności swojego narodu. Nutę szowinizmu można tutaj znaleźć w stwierdzeniu Miloševicia: ,Zwłaszcza Serbowie przez całą swoją historię nigdy nie podbijali i eksploatowali innych. Ich narodowe i historyczne istnienie przez całą historię i w ciągu dwóch wojen światowych, jak i dzisiaj jest - wyzwoleńcze".

\footnotetext{
${ }^{52}$ O „szlachetnym krzyżu” zob. M. Popović, Vidovdan i časni krst, Beograd 1976, s. 103-116.

${ }^{53}$ Przemówienie Slobodana Miloševicia z Berane z 20 września 2000 r., https:/www.youtube.com/watch?v== MBvSh3Qbro, (dostęp: 05.01.2020).

${ }^{54}$ We wrześniu 1986 roku belgradzki dziennik ,,Večernje novosti” opublikował wersję roboczą Memorandum SANU. O dokumencie tym zob. K. Mihailović, V. Krestić, ,,Memorandum SANU”. Pod udarima politike, Borba, Beograd 2002.
} 
Zakamuflowana aluzja serbskiego prezydenta do Memorandum SANU nie była przypadkowa. Mianowicie przygotowującemu się do pierwszych wolnych wyborów Miloševiciowi zależało na zjednaniu sobie serbskich intelektualistów ${ }^{55}$. Z drugiej zaś strony, obchody 600-lecia bitwy na Kosowym Polu stały się momentem przypieczętowania sojuszu Miloševicia z Serbską Cerkwią Prawosławną (SCP) i powrotu tej organizacji religijnej na scenę polityczną. Przypomnijmy, że uroczystościom państwowym towarzyszyły szumne obchody organizowane przez SCP, w tym peregrynacja relikwii księcia Lazara. Wówczas to utarło się pojęcie ,niebiańskiej Serbii" ${ }^{56}$.

W języku polityki wygłoszonego na Gazimestanie przemówienia Miloševicia można zauważyć postępującą w jego frazeologii tendencję odchodzenia od słownictwa stricte komunistycznego. Co prawda serbski prezydent zaczyna to wystapienie od klasycznego zawołania „Towarzyszki i towarzysze” („Drugarice i drugovi”), to jednak w całym przemówieniu tylko w jednym zdaniu nawiązuje do socjalizmu. I zgodnie z nowomową,,antybiurokratycznej rewolucji” nie odwołuje się już do „braterstwa i jedności”. Milošević słowa ,jedność” używa tylko w kontekście serbskim, a „braterstwo” stosuje jedynie w zawołaniu kończącym przemówienie „Niech żyje pokój i braterstwo między narodami” (,Neka živi mir i bratstvo među narodima!”).

Komentator serbskiej telewizji liczbę obecnych na Gazimestanie określił na „około półtora miliona”. Zapewne jednak większość skupionej tam podekscytowanej publiczności nie była w stanie zrozumieć zakamuflowanych politycznych podtekstów przemówienia Miloševicia. Zgromadzony tłum mógł jedynie wychwycić znane z tradycji serbskiej postacie (Miloš Obilić) oraz stare i nowe slogany: ,zgoda”, „,bohaterstwo”, ,zdrada”, „bitwy”, „jedność”, „zagrożenia jednej nacji od drugiej”, „serce Serbii”. W tym przemówieniu miały ono zastąpić to, czego tłum na pewno się domagał - czyli bezpośrednich haseł wymierzonych w inne narody Jugosławii.

Utarte przez mit kosowski slogany zauważalne są także w relacjach prezentowanych w serbskich środkach masowego przekazu. Kontrolowane wówczas przez Miloševicia belgradzkie media przedstawiły uroczystości na Gazimestanie jako spektakularny sukces prezydenta Serbii. Tak w magazynie „Ilustrovana Politika” na okładce znalazła się deklaracja „Mamy z czym przed Miloša" ${ }^{57}$. Natomiast dziennik „,Večernje novosti” na pierwszej stronie zamieścił tytuł przemówienia Miloševicia „Zgodą do prosperity”58.

W zapisie transmisji telewizyjnej wystąpienia Miloševicia na Gazimestanie można zauważyć, że gdy zakończył przemówienie, grupa jego zwolenników zaczęła intonować pieśń „Kto to mówi, kto to kłamie, Serbia jest mała” („Ko to kaže, ko to laže, Srbija je mala"). W czasach wojen jugosłowiańskich utwór stał się nieformalnym hymnem serbskich bojowników.

${ }^{55}$ N. Tromp, Smrt u Hagu. Nezavršeno suđenje Slobodanu Miloševiću, Sarajevo 2019, s. 113-117.

${ }^{56}$ Đ. Jevtić, op. cit., s. 231-234; J. Byford, Potiskivanje i poricanje antisemitizma. Sećanje na vladiku Nikolaja Velimirovića u savremenoj srpskoj pravoslavnoj kulturi, Beograd 2005, s. 73-74. Mira Marković sojusz jej męża z SCP nazywa „pierwszym przyczynkiem do serbskiej zgody”, zob. M. Marković, op. cit., s. $290-291$.

${ }^{57}$ „Ilustrovana Politika”, 4 VII 1989, s. 1.

58 „Večernje novosti”, 29 VI 1989, s. 1. 


\section{Epilog}

Przemówienie Miloševicia z Gazimestanu pojawiło się jako element aktu oskarżenia wniesionego przeciwko niemu przez Geoffreya Nice`a w trakcie procesu w Hadze (dowód rzeczowy D251) ${ }^{59}$. Oczywiście istota tego zarzutu skupiała się głównie na stwierdzeniu serbskiego prezydenta o zbrojnych bitwach. Sam Milošević w replice na wspomniany zarzut zaprzeczał, aby w tym zdaniu były jakieś ukryte inspiracje wojenne: „Co chcecie udowodnić poprzez zacytowanie jednego zdania z mojego przemówienia z Gazimestanu, które było, mogę Wam to powiedzieć, jednym bardzo dobrym przemówieniem, powiedziałbym, doskonałym przemówieniem, któremu w rzeczy samej nie ma co zarzucić. Zacytowaliście jedynie końcówkę zdania, w którym mówię, że nas czekają liczne bitwy, które oczywiście nie są zbrojne, chociaż ani takie jeszcze nie są wykluczone. To jest jedno ogólne zdanie, którego dzisiaj każdy używa, ponieważ pokój nadal nie jest pewną i stabilną kategorią we współczesnym świecie. W końcu, dlaczego istnieją armie we wszystkich państwach, kiedy by to było tak (pokojowo), to kto by się tym zajmował. Ale teraz bardzo przebiegle pomijacie wszystko inne". W dalszej części swojej obrony Milošević cytował większe fragmenty przemówienia z Gaziemestanu, podkreślając, że on miał na myśli tylko „główną bitwę o ekonomiczny, socjalny, kulturalny dobrobyt”. Były serbski lider podkreślił także, że: „Nawet dzisiaj nie zmieniłbym w nim ani jednego słowa. I wtedy uważałem, przede wszystkim ja, jako prezydent Serbii, że Serbom trzeba powiedzieć tutaj, gdzie są większością, iż narodowe równouprawnienie jest jedynym kluczem”. Milošević jednocześnie zarzucił komentatorom jego przemówienia złośliwą nadinterpretację ${ }^{60}$.

Nieprzypadkowo też pierwszym świadkiem oskarżenia w tym procesie był Albańczyk Mahmut Bakali, który w latach 1971-1981 sprawował funkcję przewodniczącego ZKK. W trakcie przesłuchania stwierdził on, że przemówienie na Gazimestanie „wyglądało jak projekt wojny" ${ }^{61}$. W odpowiedzi Milošević zarzucił mu mówienie nieprawdy pod przysięgą tym bardziej iż Bakali dodatkowo przeinaczył fakty, mówiąc, że konstytucja Serbii została zmieniona po 28 czerwca 1989 roku, a tak naprawdę doszło do tego trzy miesiące wcześniej ${ }^{62}$.

Milošević, chcąc bronić treści swojego przemówienia na Gazimestanie, powołał także swojego świadka. Był nim profesor Mihailo Marković, jeden ze współautorów Memorandum SANU. Marković na prośbę byłego serbskiego prezydenta podzielił się swoimi wrażeniami z ówczesnych uroczystości na Gazimestanie: ,,To było wielkie wydarzenie z udziałem ogromnej masy ludzi. Zachodnie źródła oceniały, że było tam zebranych wtedy około miliona ludzi i wy wygłosiliście tam bardzo pozytywne przemówienie. Na początku chwalone, a później ostro krytykowane ze strony tych samych mediów”. W dalszej części Mar-

\footnotetext{
${ }^{59}$ N. Tromp, op.cit., s. 328; Proces Slobodana Miloševicia. (IT-02-54). Međunarodni krivični tribunal za bivšu Jugoslaviju. Uvodna reč Tužilaštvo, 12 lutego 2002. Fond za humanitarno pravo, s. 20-22.

${ }^{60}$ Proces Slobodana Miloševicia. (IT-02-54). Međunarodni krivični tribunal za bivšu Jugoslaviju. Uvodna reč optuženog Miloševića, 14 lutego 2002. Fond za humanitarno pravo, s. 166-168.

${ }^{61}$ Proces Slobodana Miloševicia. (IT-02-54). Međunarodni krivični tribunal za bivšu Jugoslaviju. Uvodna reč optuženog Miloševića. Svedok Mahmut Bakali, 18 lutego 2002. Fond za humanitarno pravo, s. 303-306.

${ }^{62}$ Proces Slobodana Miloševicia. (IT-02-54). Međunarodni krivični tribunal za bivšu Jugoslaviju. Svedok Mahmut Bakali, 19 lutego 2002. Fond za humanitarno pravo, s. 335-339. Zob. G. Civikov, Proces Miloszewicia. Relacja obserwatora, Warszawa 2009, s. 32-33.
} 
ković przypomniał, że obecni tam wówczas korespondenci BBC i „The Independent” bardzo pozytywnie skomentowali przemówienie. Zdaniem profesora: „oni wyrazili swoje zaskoczenie z bardzo spokojnego i tolerancyjnego przemówienia, co się nawet nie podobało niektórym z obecnych, którzy oczekiwali, że zaatakujecie albański terroryzm". Sędzia Patrick Robinson przerwał jednak Markoviciowi, kiedy ten stwierdził: „Dziesięć lat później, kiedy nastał ten period satanizacji, i wtenczas się mówiło, że wy wygłosiliście jedno ogniste, straszne, histeryczne przemówienie. Niby zgalwanizowaliście tę całą masę najgorszymi szowinistycznymi doznaniami. To było już po reakcjach »The New York Times« i londyńskiego »Timesa«, a nawet »The Washington Post«"63.

Następnego dnia przesłuchania prokurator Nice, przeprowadzając analizę przemówienia Miloševcia z Gazimestanu, próbował wydobyć z Markovicia korzystne dla oskarżenia zeznania. Serb jednak umiejętnie zbijał tropy niezbyt zorientowanego w niuansach polityczno-historycznych oskarżyciela. Nice nie potrafił obalić twierdzenia serbskiego profesora, że Milošević: „,mówił o potrzebie narodowej równoprawności, on mówił o tolerancji. On w ani jednym słowie w ogóle nie wspomniał Kosowa, ani Albanii, ani Albańczyków"64.

W całej karierze politycznej Slobodana Miloševicia przemówienie wygłoszone na Gazimestanie 28 czerwca 1989 roku w 600-lecie bitwy na Kosowym Polu było jego najbardziej spektakularnym wystąpieniem publicznym. Nie będzie także przesady w stwierdzeniu, że było ono też jego największym sukcesem politycznym, który pozwolił mu osiagnąć pełnię władzy w Serbii. Wydaje się jednak, że jego wielkim błędem politycznym było przekierowanie rozbudzonego na Kosowie wielkoserbskiego nacjonalizmu na terytorium Chorwacji i $\mathrm{BiH}^{65}$. Perfekcyjnie zostało to wykorzystane przez kreatorów wielkoalbańskiej polityki w Kosowie, którzy przyjęli taktykę wyczekiwania na ,wykrwawienie się” Serbii w wojnie na kilka frontów. W rezultacie doprowadziło to do sankcji ekonomicznych, izolacji międzynarodowej oraz bombardowania Serbii i Czarnogóry przez NATO w 1999 roku. Kosowo przy minimalnym zaangażowaniu militarnym Albańczyków stało się ich niepodległym i niemal czystym etnicznie państwem. Wielka Albania w odróżnieniu od Wielkiej Serbii stała się faktem.

Analizując w kontekście ostatecznej klęski i upadku Miloševicia tekst jego przemówienia z Gazimestanu, można pokusić się o zadanie pytania: Czy serbski prezydent już wtedy planował konflikt zbrojny na terenie Jugosławii? Na pewno kluczowe dla odpowiedzi na nie jest cytowane już wcześniej stwierdzenie Miloševicia: „Dzisiaj, sześć wieków później, znowu jesteśmy w bitach i przed bitwami. One nie są zbrojne, chociaż i takie nie sa jeszcze wykluczone". Po latach wydaje się, że nie było ono przypadkowe, a Milošević z punktu widzenia taktyki bardzo niefortunie ujawnił swoje cele. Mianowicie serbski prezydent, zdając sobie sprawę z postępującego rozpadu Jugosławii, już wtedy planował wzmocnić pozycję Serbów w Chorwacji i BiH przez wywalczenie dla nich „w bitwach”

\footnotetext{
${ }^{63}$ Proces Slobodana Miloševicia. (IT-02-54). Međunarodni krivični tribunal za bivšu Jugoslaviju. Svedok Mihailo Marković, 16 listopada 2004. Fond za humanitarno pravo, s. 145-146.

${ }^{64}$ Proces Slobodana Miloševicia. (IT-02-54). Međunarodni krivični tribunal za bivšu Jugoslaviju. Svedok Mihailo Marković, 17 listopada 2004. Fond za humanitarno pravo, s. 200-201.

${ }^{65}$ Ivan Stambolić twierdził, że Milošević dał się ponieść emocjom kosowskich Serbów: „Jego wciągnęła ta atmosfera i dolał oleju do ognia. I problem nie polegał na tym, że on go dolał w kontekście sytuacji Serbów w Kosowie, ale że to się stało wezwaniem dla wszystkich Serbów”, zob. serial BBC - „The Death of Yugoslavia” (odc. 1, 1995).
} 
odrębności terytorialnej. Chodziło tutaj zarówno o „bitwy” polityczne, jak i te zbrojne stworzenie serbskich ,republik” w Chorwacji i BiH.

28 czerwca 2001 roku Slobodan Milošević został wydany Międzynarodowemu Trybunałowi Karnemu w Hadze. W momencie przekazywania, Milošević miał zadać serbskim policjantom pytanie: „Czy wy wiecie, że dzisiaj jest Vidovdan?”66.

\section{Bibliografia}

Aleksić B., Kosovo i kosovski zavjet u Njegoševom književnom djelu, „Godišnjak Fakulteta za kulturu i medije", nr 9, R. IX, Beograd, 2017, s. 311-322.

Andrić I., Njegoš jako tragiczny bohater kosowskiej idei, [w:] We własnych oczach. XX-wieczny esej zachodnio- i poludniowosłowiański, red. H. Janaszek-Ivaničkowa, Warszawa 1977, s. 218-238.

Antonić S., Još nije gotovo - Milošević, Beograd 2015.

Barić N., Srpska pobuna u Hrvatskoj 1990-1995, Zagreb 2005.

Blagojević M., Petrović R., Seobe Srba i Crnogoraca sa Kosova i iz Metohije, Beograd 1989.

Byford J., Potiskivanje i poricanje antisemitizma. Sećanje na vladiku Nikolaja Velimirovića u savremenoj srpskoj pravoslavnoj kulturi, Beograd 2005.

Civikov G., Proces Miloszewicia. Relacja obserwatora, Warszawa 2009.

Czamańska I., J. Leśny, Bitwa na Kosowym Polu 1389, Poznań 2015.

Čolović I., Sve je počelo u Srbiji?, [w:] Zid je mrtav, živeli zidovi!, Beograd 2009, s. 37-57.

Dedijer V., Sarajewo 1914, t. II, Łódź 1984.

Dizdarević R., Od smrti Tita do smrti Jugoslavije, Sarajevo 2000.

Gavrilović Ž., Kosovski zavet srpskog naroda, Beograd 1989.

Gil D., Prawosławie. Historia. Naród. Miejsce kultury duchowej w serbskiej tradycji i współczesności, Kraków 2005.

Intervju: Miroslav Šolević, „Vreme”, nr 454, 18 września 1999.

Jevtić Đ., Bitka za Kosovo. Šest vekova posle, t. I, Beograd 1995.

Jović B., Knjiga o Miloševiću, Beograd 2001.

Jović D., Jugoslavija - država koja je odumrla. Uspon, kriza i pad Kardeljeve Jugoslavije (1974-1990), Zagreb 2003.

Jović D., Osma sednica: uzroci, značaj, interpretacije, [w:] Slobodan Milošević - put ka vlasti (Osma sednica CK SKS), Beograd 2008, s. 33-67.

Karabeg O., Kosovski mit kamen o vratu Srbije, Wywiad z Svetlaną Slapšak i Ivanem Čoloviciem dla Radia Wolna Europa, https://www.slobodnaevropa.org/a/most_kosovo_mit/1620087.html, (dostęp: 05.01.2020).

Korzeniewska-Wiszniewska M., Serbia pod rzqdami Slobodana Miloševicia. Serbska polityka wobec rozpadu Jugosławii w latach dziewięćdziesiatych XX w., Kraków 2008.

Kosovski čvor. Drešiti ili seći?, ed. S. Popović, D. Janča, T. Petovar, Beograd 1990.

Królewicz Marko. Narodowe pieśni serbskie, przekład R. Zmorski, Warszawa 1859.

Luković M., Kryzys kosowski oczyma Serbów, Belgrad 2000.

Malcolm N., Kosovo. A Short History, New York 1998.

Marković M., Bilo je to ovako, t. I, Beograd 2015.

Mihaljčić R., Junaci kosovske legende, Beograd 1989.

Mihaljčić R., Lazar Hrebeljanović. Istorija, kult, predanje, Beograd 2001.

\footnotetext{
${ }^{66}$ S. Antonić, Još nije gotovo - Milošević, Beograd 2015, s. 420.
} 
Mihailović K., Krestić V., „Memorandum SANU”. Pod udarima politike, Borba, Beograd 2002. Milosavljević O., Antibirokratska revolucija 1987-89, [w:] Dijalog povjesničara istoričara, t. VIII, Zagreb, 2004, s. 319-336.

Milošević S., Godine raspleta, Beograd 1989.

Milošević S., Prilog istoriji dvadesetog veka, Beograd 2008.

Nikolić K., Kako je Slobodan Milošević izabran za vođu srpskih komunista (II), „Istorija 20 veka”, 2/2006, s. 105-123.

Nikolić K., „Niko ne sme da vas bije”. Slobodan Milošević u Kosovu Polju 24-25. april 1987, Beograd 2006.

Nikolić K., Obnavljanje parlamentarnog poretka u Srbiji 1990, „Tokovi istorije”, nr 2, 2011, s. $132-152$.

Orbini M., Kraljevstvo Slavena, Zagreb 1999.

Pamiętniki Janczara czyli Kronika Turecka Konstantego z Ostrowicy napisana między r. 1496 a 1501, Kraków 1912.

Petar Njegoš, Wybór pism, tłum. H. Batowski, Wrocław-Kraków 1958.

Pieśni narodowe serbskie. Bój na Kosowem polu (Lazarica), przekład R. Zmorski, Warszawa-Kraków 1913.

Popov N. Serbski dramat. Od faszystowskiego populizmu do Miloševicia, Warszawa 1994.

Popović M., Vidovdan i časni krst, Beograd 1976.

Proces Slobodana Miloševicia. (IT-02-54). Međunarodni krivični tribunal za bivšu Jugoslaviju. Uvodna reč Tužilaštvo, 12 lutego 2002. Fond za humanitarno pravo.

Proces Slobodana Miloševicia. (IT-02-54). Međunarodni krivični tribunal za bivšu Jugoslaviju. Uvodna reč optuženog Miloševića, 14 lutego 2002. Fond za humanitarno pravo.

Proces Slobodana Miloševicia. (IT-02-54). Međunarodni krivični tribunal za bivšu Jugoslaviju. Uvodna reč optuženog Miloševića. Svedok Mahmut Bakali, 18 lutego 2002. Fond za humanitarno pravo.

Proces Slobodana Miloševicia. (IT-02-54). Međunarodni krivični tribunal za bivšu Jugoslaviju. Svedok Mahmut Bakali, 19 lutego 2002. Fond za humanitarno pravo.

Proces Slobodana Miloševicia. (IT-02-54). Međunarodni krivični tribunal za bivšu Jugoslaviju. Transkripti. Przesłuchanie Stipe Mesicia, 1 października 2002. Fond za humanitarno pravo.

Proces Slobodana Miloševicia. (IT-02-54). Međunarodni krivični tribunal za bivšu Jugoslaviju. Svedok Mihailo Marković, 16 listopada 2004. Fond za humanitarno pravo.

Proces Slobodana Miloševicia. (IT-02-54). Međunarodni krivični tribunal za bivšu Jugoslaviju. Svedok Mihailo Marković, 17 listopada 2004. Fond za humanitarno pravo.

Proces Slobodana Miloševicia. (IT-02-54). Međunarodni krivični tribunal za bivšu Jugoslaviju. Transkripti. Przesłuchanie Mitara Balevicia, 9 lutego 2005. Fond za humanitarno pravo.

Przemówienie Slobodana Miloševicia na Gazimestanie z 28 czerwca 1989 r., https://www.youtube. com/watch?v=vdU6ngDhrAA, (dostęp: 05.01.2020).

Przemówienie Slobodana Miloševicia z Berane z 20 września 2000 r., https://www.youtube.com/ watch?v=-MBvSh3Qbro, (dostęp: 05.01.2020).

Rapacka J., Godzina Herdera, Warszawa 1995.

Repe B., Jutri je nov dan. Slovenci in razpad Jugoslavije, Ljubljana 2002.

Serial BBC - „The Death of Yugoslavia” (odc. 1, 1995).

Stambolić I., Put u bespuće, Beograd 1995.

Šćekić R., „, Događanje naroda” u Crnoj gori. Političko-propagandni okvir, „Matica”, wiosna 2011, s. 295-328.

Tomas R., Srbija pod Miloševićem. Politika devedesetih, Beograd 2002.

Tromp N., Smrt u Hagu. Nezavršeno suđenje Slobodanu Miloševiću, Sarajevo 2019.

Vllasi A., Kosovo, početak raspada, Sarajevo 2016. 
Vllasi A., Dan kada je Milošević objavio rat!, „Dnevni avaz”, 28.06.2019.

Zacharias M. J., Komunizm, federacja, nacjonalizmy. System władzy w Jugostawii 1943-1991. Powstanie, przekształcenia, rozkład, Warszawa 2004.

Zieliński B., Serbska powieść historyczna, Poznań 1998.

Żurek P., Styl i frazeologia języka polityki przemówień Slobodana Miloševicia z lat 1984-89, [w:] Rozwarstwienia stylistyczne języków stowiańskich. Style funkcjonalne i stylizacje literackie, Katowice 1996, s. 151-156.

Żurek P., Stowenia w walce o niepodległość (1980-1992). Wyjść z cienia Jugosławii, Kraków 2019.

Piotr Żurek, dr hab., profesor Akademii Techniczno-Humanistycznej w Bielsku-Białej. Ukończył historię i slawistykę na Uniwersytecie Śląskim w Katowicach. W 2003 roku doktoryzował się na Wydziale Historycznym Uniwersytetu Warszawskiego. Habilitację uzyskał w 2011 roku na Wydziale Nauk Społecznych Uniwersytetu Śląskiego. Autor krajowych i zagranicznych publikacji naukowych poświęconych problematyce południowosłowiańskiej. Jego zainteresowania językoznawcze obejmują zagadnienia kontaktu językowego i języka polityki. 